\title{
CYANIDIN AND PEONIDIN INHIBIT SPCA-1 GROWTH IN VITRO VIA INDUCING CELL CYCLE ARREST AND APOPTOSIS
}

\author{
HENG YUE ${ }^{1,2}$, QIANQIAN XU ${ }^{1,2}$, LIUZHUANG LV ${ }^{1}$, HUA FAN ${ }^{3}$, JIANFENG XU ${ }^{1,2 *}$ \\ and WENHAN WANG ${ }^{4 *}$ \\ ${ }^{1}$ Department of Biopharmaceutics, College of Food Science and Technology, \\ Shanghai Ocean University, Shanghai, China \\ ${ }^{2}$ Quality Supervision, Inspection and Testing Center for Cold Storage \\ and Refrigeration Equipment, Ministry of Agriculture, Shanghai 201306, China \\ ${ }^{3}$ Institute für Laboratoriumsmedizin, Charite-Universitatsmedizin Berlin Campus Virchow-Klinikum, \\ Berlin, Germany \\ ${ }^{4}$ Institute of Edible Fungi, Shanghai Academy of Agricultural Sciences, Key Laboratory of Edible Fungi \\ Resources and Utilization (South) Shanghai, China

\begin{abstract}
Non-small cell lung cancer (NSCLC) accounts for the majority (85\%) of all lung cancers. Although many therapies are available, 35-50\% of patients with stage I or II NSCLC develop recurrence and metastasis. This study was designed to investigate the anti-tumor activity of cyanidin (Cy) and peonidin (Pn) on NSCLC cells (SPCA-1). SPCA-1 cell proliferation, cell cycle and early apoptosis were investigated after treatment with $\mathrm{Cy}$ and $\mathrm{Pn}$. The underlying signaling mechanism was also explored by detecting the levels of apoptosis-related proteins using enzyme-linked immunosorbent assay (ELISA). Cy and Pn inhibited the viability of SPCA-1 cells with an $\mathrm{IC}_{50}$ of $141.08 \mathrm{erg} / \mathrm{mL}$ and $161.31 \mu \mathrm{g} / \mathrm{mL}$, respectively. Meanwhile, Cy and Pn induced cell cycle arrest at G2/M phase. Cy and Pn treatment significantly increased the levels of Bax, P53, and Caspase-3, while decreasing that of Bcl-2, thereby inhibiting the growth of SPCA-1 cells. In conclusion, Cy and Pn induced early apoptosis of NSCLC cells through regulation of the levels on Caspase-3, Bax, Bcl-2, and P53. These results suggest $\mathrm{Cy}$ and $\mathrm{Pn}$ as potential anticancer drugs for the treatment of lung cancer.
\end{abstract}

Keywords: SPCA-1, cyanidin, peonidin, lung cancer, apoptosis, cell cycle

Lung cancer is the most commonly diagnosed malignancy and the main cause of cancer-related deaths in Asian and Western populations, with a 5year survival rate of only approximately $15 \%(1,2)$. Non-small cell lung cancer (NSCLC) accounts for the majority $(85 \%)$ of all lung cancers, and despite two decades of surgery, radiation, and chemotherapy interventions, $35-50 \%$ of patients with stage I or II NSCLC relapse and develop metastasis (3).

5 -fluorouracil (5-FU), a pyrimidine analog, is one of the most widely used chemotherapy drugs in the treatment of a range of cancers, including breast cancer, gastrointestinal cancer, and NSCLC $(4,5)$. However, for $31 \%$ to $34 \%$ of patients, 5 -FU (Figure 1a) presents dose-limiting toxicity and even leads to death due to complete Dihydropyrimidine dehydrogenase (DPD) deficiency or partial DPD deficiency $(6,7)$. Thus, alternative and bio- compatible drugs are urgently needed to treat NSCLC.

Anthocyanidins are the most abundant watersoluble pigments present in fruit and vegetables (8). They are glycosides and acyl glycoside derivatives of six common anthocyanidins: pelargonidin, cyaniding (Cy), malvidin, delphinidin, peonidin ( $\mathrm{Pn})$, and petunidin, which are classified according to the number and position of hydroxyl groups on the flavan nucleus $(9,10)$. Some reports indicated that delphinidin and $\mathrm{Cy}$ (Figure 1b) were cytotoxic in a metastatic human colorectal cancer cell line (11, 12). Anthocyanidins have been increasingly explored for their anticancer effects. Evidence indicates that anthocyanidins have significant therapeutic activity against lung, breast, and prostate cancer $(13,14,15)$. In recent years, various studies demonstrated that cyanidin 3-glucoside and peonidin 3-

\footnotetext{
* Corresponding author: e-mail: (JX) jfxu@shou.edu.cn; (WW) wangwenhan@saas.sh.cn
} 
glucoside inhibit cell growth by blocking the cell cycle and inducing cell apoptosis of HS578T (breast cancer cell line), HT-29 (intestinal cancer cell line), and H1299 (lung cancer cell line) (16, 17, 18). Additionally, Cy suppresses ultraviolet B-induced COX-2 expression in epidermal cells by targeting MKK4, MEK1, and Raf-1 (19). Pn (Figure 1c) inhibits phorbol-ester-induced COX-2 expression and transformation in JB6 $\mathrm{P}(+)$ cells by blocking ERK-1 and -2 phosphorylation (20).

SPCA-1 cells have high metastatic ability and are the most representative NSCLC cells. Thus, this study was undertaken to evaluate the therapeutic potential of $\mathrm{Cy}$ and Pn for NSCLC treatment in comparison to that of 5-FU. We investigated whether Cy or Pn could inhibit SPCA-1 cell proliferation. We demonstrate for the first time that $\mathrm{Cy}$ and $\mathrm{Pn}$ inhibit cell growth and induce apoptosis of SPCA-1 in vitro.

\section{EXPERIMENTAL}

\section{Materials}

Cy and Pn were purchased from PhytoLab (PhytoLab GmbH \& Co. KG, Vestenbergsgreuth, Germany). The compounds were stored at $-20^{\circ} \mathrm{C}$. The purity of $\mathrm{Cy}$ and $\mathrm{Pn}$ was above $95 \%$ and $99 \%$, respectively, was measured by HPLC (The certificates were provided by the PhytoLab). SPCA-1 cell line was obtained from the Shanghai Academy of Agricultural Sciences, Shanghai, China. Culture medium (DMEM) and fetal calf serum were purchased from GIBCO (Carlsbad, CA, USA). TrypsinEDTA solution $0.25 \%$ was purchased from Fermentas (Waltham, MA, USA). Alamar Blue was purchased from AbD Serotec (Oxford, UK). Apoptosis kit was purchased from KeyGEN BioTECH Co., Ltd. (Nanjing, China). P53, Caspase3, Bcl-2, and Bax ELISA kits were purchased from Abcam (Cambridge, MA, USA). All other reagents were purchased from Sinopharm Chemical Reagent Co., Ltd. (Beijing, China).

\section{Cell culture}

A human NSCLC line, SPCA-1, was cultured in DMEM culture medium, supplemented with $10 \%$ FBS, $100 \mathrm{U} / \mathrm{L}$ penicillin, and $100 \mathrm{mg} / \mathrm{mL}$ streptomycin. The cells were cultured at $37^{\circ} \mathrm{C}$ in an incubator humidified with $5 \% \mathrm{CO}_{2}$ to reach $90 \%$ confluence and used for further experiments.

\section{Alamar blue assay}

SPCA-1 cells were diluted to a final concentration of $2 \times 10^{4}$ cells $/ \mathrm{mL}$ and dispensed into 96 -well plates $\left(100 \mu \mathrm{L}\right.$ per well) and incubated at $37^{\circ} \mathrm{C}$ in a $5 \% \mathrm{CO}_{2}$ atmosphere. Twenty-four hours later, the medium was replaced with fresh DMEM medium (100 $\mu \mathrm{L}$ ) containing 50, 100, 150, or $200 \mu \mathrm{g} / \mathrm{mL}$ Cy and Pn. DMEM medium containing 5\%o DMSO and $50 \mu \mathrm{g} / \mathrm{mL} 5$-FU served as the negative and positive controls, respectively. The experiments were performed in triplicate. After incubation at $37^{\circ} \mathrm{C}$ in a $5 \% \mathrm{CO}_{2}$ atmosphere for $72 \mathrm{~h}$, the medium was replaced with $180 \mu \mathrm{L}$ DMEM medium and $20 \mu \mathrm{L}$ Alamar blue for further incubation. When the color of the medium changed, absorbance was measured at $570 \mathrm{~nm}$ and $600 \mathrm{~nm}$ using a microplate reader (Bio-Tek Instruments, Inc, Winooski, VT, USA). The proliferation rate was calculated according to the following formula:

Proliferation rate $(\%)=1-\frac{A_{\lambda 570}(\text { sample })-A_{\lambda 600}(\text { sample })}{A_{\lambda 570}(\text { control })-A_{\lambda 600}(\text { control })} \times 100 \%$

\section{Cell-cycle analysis}

SPCA-1 cells were diluted to a final concentration of $1 \times 10^{5}$ cells $/ \mathrm{mL}$ and were dispensed into 12 well plates ( $1 \mathrm{~mL}$ per well). Medium $(1 \mathrm{~mL})$ containing 50, 100, and $200 \mu \mathrm{g} / \mathrm{mL} \mathrm{Cy}$ and Pn was added to the wells. Medium containing 5\%o DMSO and $50 \mu \mathrm{g} / \mathrm{mL} 5$-FU served as the negative and positive controls, respectively. Plates were incubated at $37^{\circ} \mathrm{C}$ in a $5 \% \mathrm{CO}_{2}$ atmosphere. Forty-eight hours later, the supernatant was discarded after centrifugation and the cells were washed with pre-cooled PBS once. Then, $70 \%$ ethanol $(500 \mu \mathrm{L})$ was added and<smiles>O=c1[nH]cc(F)c(=O)[nH]1</smiles>

a<smiles>Oc1cc(O)c2cc(O)c(-c3ccc(Cl)c(O)c3)[o+]c2c1</smiles>

b<smiles></smiles>

c

Figure1. Chemical formulas of 5-FU (a), Cy (b) and Pn (c) 
A
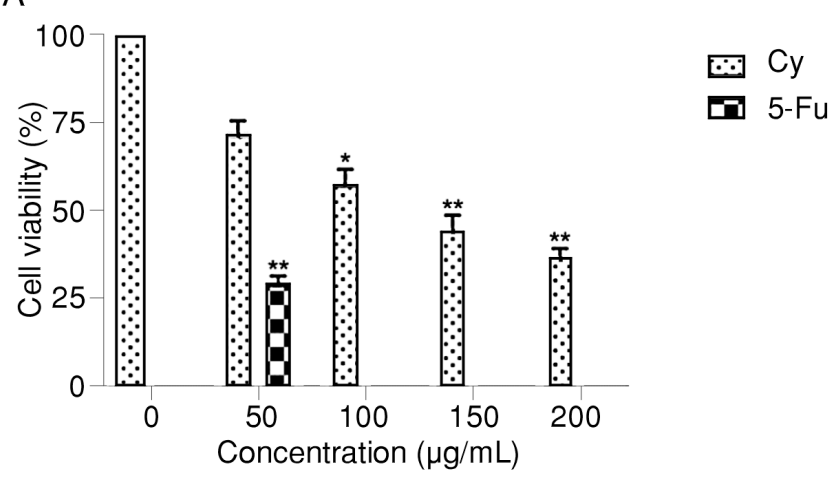

B

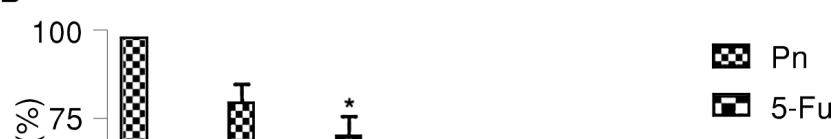

Figure 2. (A): Effect of Cy on the viability of SPCA-1 cells. (B) Effect of Pn on the viability of SPCA-1 cells. SPCA-1 cells were incubated for $72 \mathrm{~h}$ with different concentrations of cyanidin (Cy), peonidin (Pn), and $50 \mu \mathrm{g} / \mathrm{mL}$ 5-FU. Alamar Blue assay was conducted to determine the effect of $\mathrm{Cy}$ and Pn on the viability of SPCA-1 cells. Values are mean \pm SD of at least three different experiments performed in duplicate. ${ }^{*} \mathrm{p}<0.01$ compared with negative control, ${ }^{*} \mathrm{p}<0.05$ compared with negative control. Positive control: 5 -FU (50 $\left.\mu \mathrm{g} / \mathrm{mL}\right)$

the cells were incubated at $4^{\circ} \mathrm{C}$ overnight for fixation. Cells were collected by centrifugation, washed once with PBS, and $100 \mu \mathrm{L}$ PBS containing $1 \mu \mathrm{g} / \mathrm{mL}$ propidium iodide (PI) and $500 \mu \mathrm{g} / \mathrm{mL}$ RNase A were added. After incubation at room temperature for 30 min, $300 \mu \mathrm{L}$ PBS was added and Flow cytometry (counting 10000 cells) (BD Accuri C6) was performed. The results were analyzed with FlowJo software.

\section{Annexin V-FITC/PI double staining analysis by flow cytometry}

SPCA-1 cells were diluted to a final concentration of $1 \times 10^{5}$ cells $/ \mathrm{mL}$ and dispensed into a 12 -well plate $(1 \mathrm{~mL}$ per well). Medium $(1 \mathrm{~mL})$ containing 50,100 , and $200 \mu \mathrm{g} / \mathrm{mL} \mathrm{Cy}$ and Pn was added to the wells. Medium containing 5\%o DMSO and 50 $\mu \mathrm{g} / \mathrm{mL} 5$-Fu served as the negative and positive controls, respectively. After incubation at $37^{\circ} \mathrm{C}$ in a $5 \%$ $\mathrm{CO}_{2}$ atmosphere for $48 \mathrm{~h}, 0.05 \%$ EDTA was added. The supernatant was removed by centrifugation and the cells were collected. Cells were washed once with pre-cooled PBS. The supernatant was replaced with $300 \mu \mathrm{L}$ Binding Buffer to suspend the cells. After addition of $2.5 \mu \mathrm{L}$ Annexin $\mathrm{V}$ and $2 \mu \mathrm{L}$ PI, the cells the were incubated in the dark at room temperature for $15 \mathrm{~min}$. Flow cytometry (counting 10000 cells) was performed and the results were analyzed with FlowJo software.

\section{Enzyme-linked Immunosorbent Assay (ELISA)}

The levels of Caspase-3, P53, Bax, and Bcl-2 were measured by ELISA following the manufacturer's protocols. The target protein concentration was calculated and then multiplied by the dilution factor.

\section{Statistical analysis}

The results are expressed as mean \pm SD. Oneway ANOVA in SPSS 19.0 software (SPSS, Chicago, IL, USA) was used for statistical analysis. The p-values less than 0.05 were considered to be statistically significant. 


\section{RESULTS}

Cy and Pn inhibit the growth of SPCA-1 cells

Alamar Blue assay was conducted to determine the effect of Cy and Pn on SPCA-1 cell proliferation. As shown in Figure 2, Cy and Pn significantly inhibited SPCA-1 cell proliferation in a dose-dependent manner. When the concentration was $200 \mathrm{mg} / \mathrm{mL}$, the inhibitory effect of Cy and Pn was similar to that of the positive control, $5-\mathrm{Fu}(50 \mu \mathrm{g} / \mathrm{mL})$. The $\mathrm{IC}_{50}$ of Cy and Pn was $141.079 \mu \mathrm{g} / \mathrm{mL}$ and $161.312 \mu \mathrm{g} / \mathrm{mL}$, respectively. The growth inhibitory ability of $\mathrm{Cy}$ on
SPCA-1 was better than that of Pn within a certain range. The results show that $\mathrm{Cy}$ and $\mathrm{Pn}$ suppress the growth of SPCA-1 cells, and the growth inhibitory ability of Cy on SPCA-1 was better than that of Pn within a certain range.

\section{Influence of $\mathrm{Cy}$ and Pn on the cell cycle in SPCA- 1 cells}

Flow cytometry allows us to determine changes to the cell cycle, which is related to tumor cell proliferation. The results are shown in Figure 3, Cy and Pn induced a decrease in the percentage of cells in G0/G1 and S phases. Meanwhile, Cy and Pn
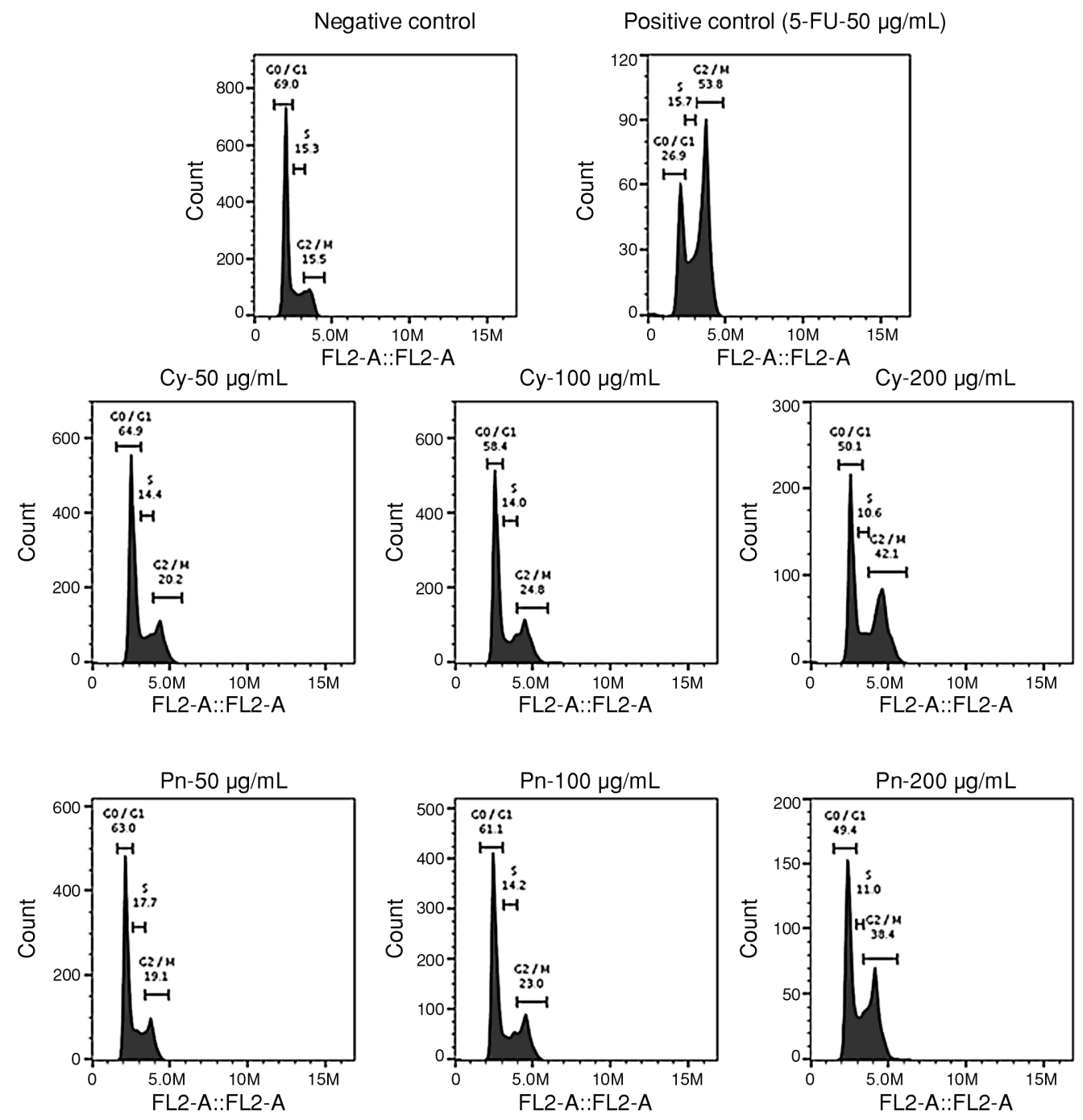

Figure 3. Effect of different concentrations of Cy and Pn on SPCA-1 cell cycle. SPCA-1 cells were incubated for $48 \mathrm{~h}$ with different concentrations of $\mathrm{Cy}, \mathrm{Pn}$, and 5-FU $(50 \mu \mathrm{g} / \mathrm{mL})$. Cell cycle was assessed by flow cytometry using PI staining 

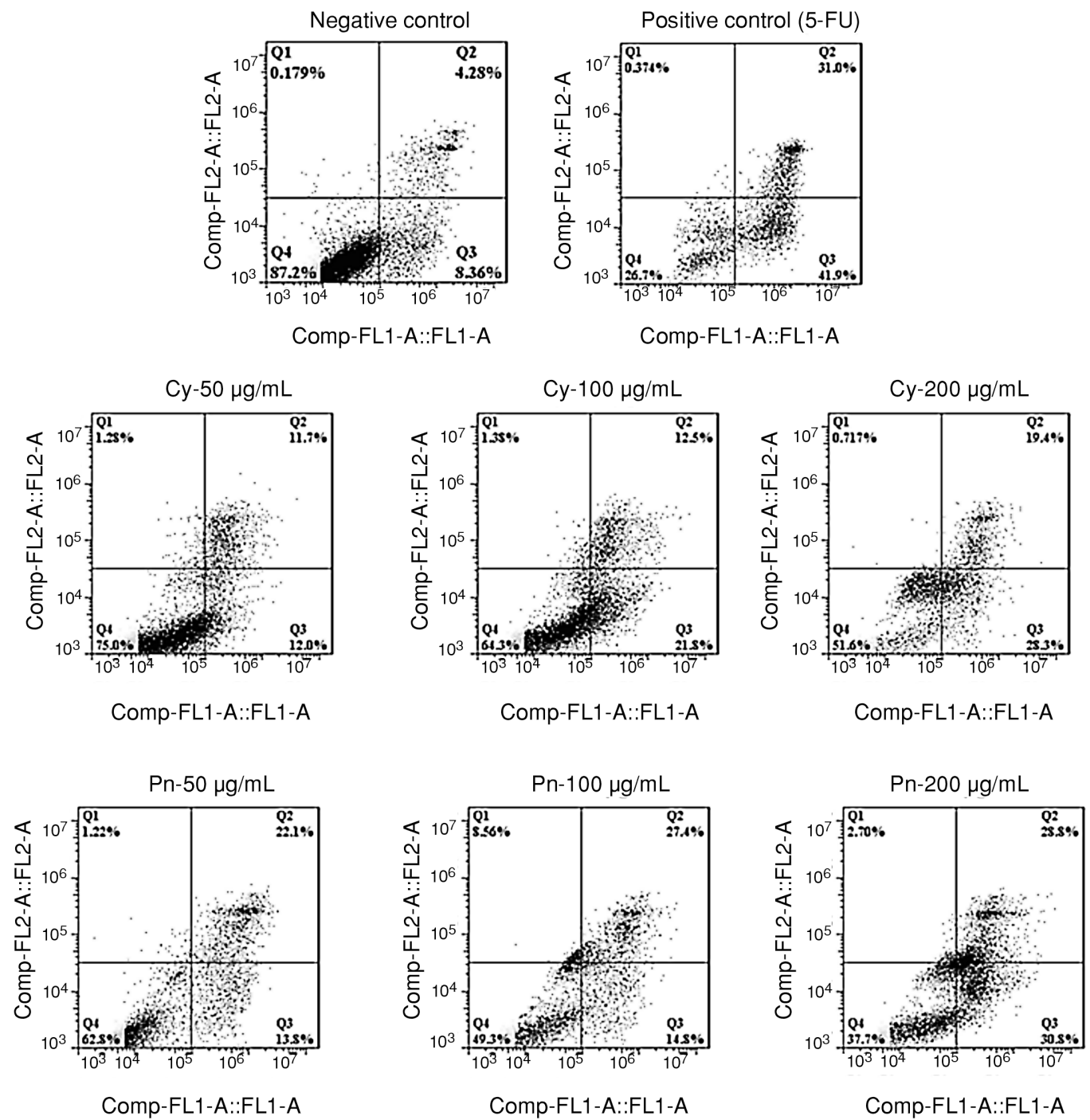

Figure 4. Effects of different concentrations of Cy and Pn on early apoptosis of SPCA-1 cells. SPCA-1 cells were incubated for $48 \mathrm{~h}$ with different concentrations of $\mathrm{Cy}, \mathrm{Pn}$, and 5-FU $(50 \mu \mathrm{g} / \mathrm{mL})$. Cell apoptosis was assessed by flow cytometry using Annexin V-FITC and PI double staining

induced an increase in the percentage of cells in G2/M phase. The results indicated that $\mathrm{Cy}$ and $\mathrm{Pn}$ induced cell cycle arrest at the G2/M phase.

\section{Induction of apoptosis}

Decrease in cell proliferation is closely related to early apoptosis. Thus, we assessed early apoptosis of SPCA-1 cells by Annexin V-FITC and PI double staining using a flow cytometer. The early apoptosis rates after treatment with 50, 100, $200 \mu \mathrm{g} / \mathrm{mL}$ Cy and Pn were $12.0 \%, 19.7 \%, 21.8 \%$ and $13.8 \%$, $14.8 \%, 30.8 \%$, respectively, which were higher than that in the negative control (Figure 4). This result suggests that $\mathrm{Cy}$ and Pn cause early apoptosis in SPCA-1 cells in a dose-dependent manner.

Effect of $\mathrm{Cy}$ and Pn on the levels of apoptotic proteins (Caspase-3, P53, Bax, and Bcl-2) in SPCA-1 cells

Apoptosis is an active and programmed death process, which is precisely regulated by many genes under certain physiological or pathological conditions (21). Also, apoptosis is closely related to apoptosis-related proteins. Therefore, we investigated the 
effect of Cy and Pn on the levels of the apoptotic proteins in SPCA-1 cells.

As shown in Figure 5A, SPCA-1 cells were treated with different concentrations of $\mathrm{Cy}, \mathrm{Pn}$, and 5-FU for $48 \mathrm{~h}$. Compared with the negative group, the level of Caspase- 3 increased in the treated groups. Cy and $\mathrm{Pn}$ at the concentration of 200 $\mu \mathrm{g} / \mathrm{mL}$ significantly affected the level of Caspase- 3 when compared with the negative group $(p<0.01)$. Furthermore, Pn at the concentration of $200 \mu \mathrm{g} / \mathrm{mL}$ increased the level of Caspase-3 to a level similar to that induced by $5-\mathrm{Fu}(50 \mu \mathrm{g} / \mathrm{mL})$.

As shown in Figure 5B, SPCA-1 cells were treated with different concentrations of $\mathrm{Cy}, \mathrm{Pn}$, and 5-FU for $48 \mathrm{~h}$ and the level of P53 increased compared to that in the negative control group. Compared with the negative control group, Cy (50 $\mu \mathrm{g} / \mathrm{mL})$ and $\mathrm{Pn}(50 \mu \mathrm{g} / \mathrm{mL})$ showed no significant difference. However, 5 -FU at $50 \mu \mathrm{g} / \mathrm{mL}$ as well as $\mathrm{Cy}$ and $\mathrm{Pn}$ at 100 and $200 \mu \mathrm{g} / \mathrm{mL}$ significantly affected the level of P53 ( $<<0.01$ ). Cy and Pn at $200 \mu \mathrm{g} / \mathrm{mL}$ had effects similar to that of $5-\mathrm{Fu}$ at 50 $\mu \mathrm{g} / \mathrm{mL}$ on the level of P53.

The level of Bax increased after Cy, Pn, and 5FU treatment when compared to that in the negative control (Figure 5C). Compared with the negative control group, $50 \mu \mathrm{g} / \mathrm{mL} 5$-FU and 50, 100, and 200 $\mu \mathrm{g} / \mathrm{mL}$ Cy significantly increased the level of Bax $(\mathrm{p}<0.01)$, while Pn only had a significant effect at $200 \mu \mathrm{g} / \mathrm{mL}(\mathrm{p}<0.01)$. The effect of Cy on the level of Bax was more obvious than $\mathrm{Pn}$. When the cells was treated with $200 \mu \mathrm{g} / \mathrm{mL}$ of $\mathrm{Cy}$, the level of Bax was similar to that in cells treated with $5-\mathrm{FU}(50 \mu \mathrm{g} / \mathrm{mL})$.

However, when the $\mathrm{Cy}, \mathrm{Pn}$, and 5-FU groups were compared with the negative control group, the level of Bcl-2 was decreased (Figure 5D). A significant decrease in the level of Bcl-2 was observed after treatment with $50 \mu \mathrm{g} / \mathrm{mL}$ of $5-\mathrm{FU}$ and 200 $\mu \mathrm{g} / \mathrm{mL}$ of Cy and Pn $(\mathrm{p}<0.01)$. Cy at concentrations of 50 and $100 \mu \mathrm{g} / \mathrm{mL}$, but not Pn at the same concentrations affected the level of Bcl-2 $(\mathrm{p}<0.05)$. The effect of $\mathrm{Cy}$ on the level of Bcl-2 was more obvious than Pn. The level of Bcl-2 was similar to that in the positive control $(50 \mu \mathrm{g} / \mathrm{mL} 5$-FU) when the cells were treated with $200 \mu \mathrm{g} / \mathrm{mL}$ of Cy.

\section{DISCUSSION AND CONCLUSION}

In recent years, chemotherapy has been widely used to treat and prolong the life of patients with
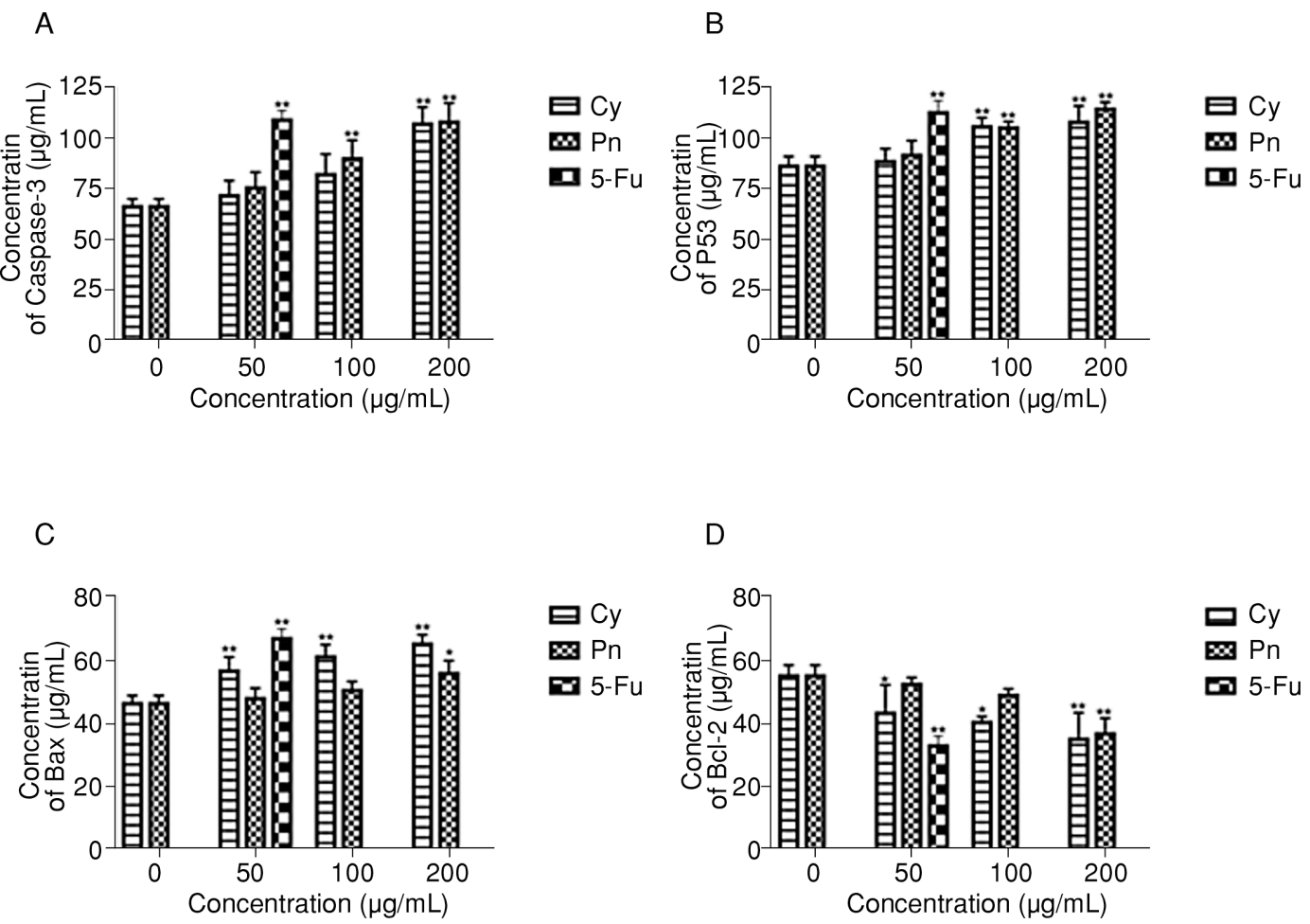

Figure 5. Effect of different concentrations of Cy and Pn on the level of Caspase-3 (Figure 5A), P53 (Figure 5B), Bax (Figure 5C) and Bcl2 (Figure 5D) in SPCA-1 cells. The level of Caspase-3, P53, Bax, and Bcl-2 were measured with ELISA kits. **p $<0.01$ compared with negative control, $* \mathrm{p}<0.05$ compared with negative control 
NSCLC. Numerous experiments confirmed that active ingredient from natural products such as triterpenoids, alkaloids, polysaccharides, saponins, and other active substances could be used to treat malignant tumors and reduce the side effects of chemotherapy $(22,23,24,25)$. Additionally, various studies recently reported that anthocyanins could inhibit cellular transformation and cell-cycle progression, and induced apoptosis in different human cell lines $(13,26,27,28)$.

Treatment with peonidin 3-glucoside and cyanidin 3-glucoside inhibits cell growth of human breast cancer and treatment with $\mathrm{Cy}$ inhibits the growth of human monocytic leukemia cells via G2/M arrest and induction of apoptosis $(16,29)$. In this study, Cy and Pn affected the cell cycle at the G2/M phase in SPCA-1 cells. Therefore, we considered that early apoptosis induced by $\mathrm{Cy}$ and Pn in SPCA-1 cells was associated with $\mathrm{G} 2 / \mathrm{M}$ phase arrest. Meanwhile, our study suggests that $\mathrm{Cy}$ and $\mathrm{Pn}$ induce apoptosis of SPCA-1 cells in a dose-dependent manner. Furthermore, we explored the mechanism underlying $\mathrm{Cy}$ and $\mathrm{Pn}$-induced apoptosis.

The Bcl-2 family includes Bax, Bad, and other pro-apoptotic proteins as well as anti-apoptosis proteins such as Bcl-2 and Bcl-xL. Most of them are composed of a C-terminal transmembrane domain and a Bcl-2 homology domain $(30,31)$. Moreover, the caspase family plays a key role in the execution of apoptosis (32). Caspases are the most important enzymes for apoptosis (33), inducing chromatin condensation, DNA fragmentation, and finally apoptosis. P53 is also an important regulator of apoptosis. It interacts with $\mathrm{Bcl}-2$ in the process of apoptosis, thereby regulating cell apoptosis (34). The present study showed that $\mathrm{Cy}$ and Pn treatment dose-dependently induced the down-regulation of Bcl-2 level and the up-regulation of levels of Caspase-3, P53, and Bax in SPCA-1 cells. Furthermore, our results suggest differences between $\mathrm{Cy}$ and Pn in term of their anti-tumor function, which may be associated with their different structures.

In conclusion, this study demonstrated that $\mathrm{Cy}$ and Pn inhibit the growth of SPCA-1 cells by inducing cell cycle arrest and early apoptosis. Additionally, Cy and Pn may induce early apoptosis through up-regulation of Caspase-3, P53, Bax, and $\mathrm{Bcl}-2$ down-regulation. Our findings suggest $\mathrm{Cy}$ and $\mathrm{Pn}$ as potential anticancer therapeutics for the treatment of lung cancer. Further studies are warranted to decipher the mechanism underlying the anti-cancer effect of anthocyanidins and for the development of anthocyanidins as therapeutics for the treatment of NSCLC.

\section{Acknowledgments}

The authors would like to thank and acknowledge the financial support of this research project by the Natural Science Foundation of the Science and Technology Commission of Shanghai Municipality (Grant No.16ZR1431000).

\section{Competing interests}

The authors declare that there is no conflict of interests regarding the publication of this paper.

\section{REFERENCES}

1. Jemal A., Murray T., Ward E., Samuels A., Tiwari R.C. et al.: CA Cancer J. Clin. 55, 10 (2005).

2. Tang J.M., He Q.Y., Guo R.X., Chang X.J.: Lung Cancer. 51, 181 (2006).

3. Egermann U., Jaeggi K., Habicht J.M., Perruchoud A.P., Dalquen P. et al.: Eur. Respir. J. 19, 464 (2002).

4. Longley D.B., Harkin D.P., Johnston P.G.: Nat. Rev. Cancer. 3, 330 (2003).

5. Huang C.L., Yokomise H., Kobayashi S., Fukushima M., Hitomi S. et al.: Int. J. Oncol. 17, 47 (2000).

6. Bocci G., Barbara C., Vannozzi F., Di Paolo A., Melosi A. et al.: Clin. Pharmacol Ther. 80, 384 (2006).

7. Bocci G., Di Paolo A., Barbara C., Masi G., Fornaro L. et al.: Br. J. Clin. Pharmacol. 67, 132 (2009).

8. Abdel-Aal el S.M., Young J.C., Rabalski I.: J. Agric. Food Chem. 54, 4696 (2006).

9. Crozier A., Jaganath I.B., Clifford M.N.: Nat. Prod. Rep. 26, 1001 (2009).

10. Kong J.M., Chia L. S., Goh N.K., Chia T.F., Brouillard R.: Phytochemistry. 64, 923 (2003).

11. Tulio A.Z., Jr., Reese R.N., Wyzgoski F.J., Rinaldi P.L., Fu R. et al.: J. Agric. Food Chem. 56, 1880 (2008).

12. Cvorovic J., Tramer F., Granzotto M., Candussio L., Decorti G. et al.: Arch. Biochem. Biophys. 501, 151 (2010).

13. Hafeez B.B., Siddiqui I.A., Asim M., Malik A., Afaq F. et al.: Cancer Res. 68, 8564 (2008).

14. Chen P.N., Chu S.C., Chiou H.L., Kuo W.H., Chiang C.L. et al.: Cancer Lett. 235, 248 (2006). 
15. Xu M., Bower K.A., Wang S., Frank J.A., Chen G. et al.: Mol. Cancer. 9, 285 (2010).

16. Chen P.N., Chu S.C., Chiou H.L., Chiang C.L., Yang S.F. et al.: Nutr. Cancer. 53, 232 (2005).

17. Serra D., Paixao J., Nunes C., Dinis T.C., Almeida L.M.: PLoS One. 8, e73001 (2013).

18. Ho M.L., Chen P.N., Chu S.C., Kuo D.Y., Kuo W.H. et al.: Nutr. Cancer. 62, 505 (2010).

19. Kim J.E., Kwon J.Y., Seo S.K., Son J.E., Jung S.K. et al.: Biochem. Pharmacol. 79, 1473 (2010).

20. Kwon J.Y., Lee K.W., Hur H.J., Lee H.J.: Ann. N. Y. Acad. Sci. 1095, 513 (2007).

21. Lowe S.W., Lin A.W.: Carcinogenesis 21, 485 (2000).

22. Mu L.H., Bai L., Dong X.Z., Yan F.Q., Guo D.H. et al.: Biol. Pharm. Bull. 37, 1035 (2014).

23. Wu G.S., Lu J.J., Guo J.J., Li Y.B., Tan W. et al.: Fitoterapia 83, 408 (2012).

24. Akl M.R., Ayoub N.M., Ebrahim H.Y., Mohyeldin M.M., Orabi K.Y. et al.: Mar. Drugs. 13, 288 (2015).
25. Yeh C.T., Wu C.H., Yen G.C.: Mol. Nutr. Food Res. 54, 1285 (2010).

26. Lazze M.C., Savio M., Pizzala R., Cazzalini O., Perucca P. et al.: Carcinogenesis. 25, 1427 (2004).

27. Han C., Ding H., Casto B., Stoner G.D., Ambrosio S.M.: Nutr. Cancer. 51, 207 (2005).

28. Huang C., Huang Y., Li J., Hu W., Aziz R. et al.: Cancer Res. 62, 6857 (2002).

29. Hyun J.W., Chung H.S.: J. Agric. Food Chem. 52, 2213 (2004).

30. Gross A., McDonnell J.M., Korsmeyer S.J.: Genes Dev. 13, 1899 (1999).

31. Farrow S.N., Brown R.: Curr. Opin. Genet. Dev. 6, 45 (1996).

32. Cryns V.L., Byun Y., Rana A., Mellor H., Lustig K.D. et al.: J. Biol. Chem. 272, 29449 (1997).

33. Thornberry N.A., Lazebnik Y.: Science 281, 1312 (1998).

34. Vazquez A., Bond E.E., Levine A.J., Bond G.L.: Nat. Rev. Drug Discov. 7, 979 (2008).

Received: 21.11 .2018 